IZA DP No. 9739

The Effect of Announced Downsizing on Workplace

Performance: Evidence from a Retail Chain

Guido Friebel

Matthias Heinz

Nick Zubanov

February 2016 


\title{
The Effect of Announced Downsizing on Workplace Performance: Evidence from a Retail Chain
}

\author{
Guido Friebel \\ Goethe University Frankfurt \\ and IZA \\ Matthias Heinz \\ University of Cologne \\ Nick Zubanov \\ Goethe University Frankfurt \\ and IZA
}

Discussion Paper No. 9739
February 2016

IZA

P.O. Box 7240

53072 Bonn

Germany

Phone: +49-228-3894-0

Fax: +49-228-3894-180

E-mail: iza@iza.org

Any opinions expressed here are those of the author(s) and not those of IZA. Research published in this series may include views on policy, but the institute itself takes no institutional policy positions. The IZA research network is committed to the IZA Guiding Principles of Research Integrity.

The Institute for the Study of Labor (IZA) in Bonn is a local and virtual international research center and a place of communication between science, politics and business. IZA is an independent nonprofit organization supported by Deutsche Post Foundation. The center is associated with the University of Bonn and offers a stimulating research environment through its international network, workshops and conferences, data service, project support, research visits and doctoral program. IZA engages in (i) original and internationally competitive research in all fields of labor economics, (ii) development of policy concepts, and (iii) dissemination of research results and concepts to the interested public.

IZA Discussion Papers often represent preliminary work and are circulated to encourage discussion. Citation of such a paper should account for its provisional character. A revised version may be available directly from the author. 
IZA Discussion Paper No. 9739

February 2016

\section{ABSTRACT}

\section{The Effect of Announced Downsizing on Workplace Performance: Evidence from a Retail Chain}

We estimate the effect of downsizing announcement on workplace performance using data from a German bakery chain of 193 shops. Faced with intensified competition, the firm decided to sell or close down 57 of its worst performing shops. We identify the effect of downsizing from a plausibly exogenous variation in the timing of the sale or closure announcement in the individual shops. We find that the announcements of the shop being sold to a new owner and being closed down reduce sales by six and 21 percent, respectively. The negative effect of downsizing increases with the share of workers with a permanent contract, even though permanent workers faced a much lower unemployment risk. We relate our findings to the literatures on downsizing and psychological contract.

JEL Classification: M12, M54

Keywords: downsizing, psychological contract, retail, teams, statistical analysis

Corresponding author:

Nick Zubanov

Goethe University Frankfurt

Faculty of Economics and Business Administration

Theodor-W.-Adorno-Platz 4

60629 Frankfurt am Main

Germany

E-mail: zubanov@econ.uni-frankfurt.de 
Downsizing, “a planned set of organizational policies and practices aimed at workforce reduction with the goal of improving firm performance” (Datta et al., 2010, p. 282), occurs all the time, attracting much public attention. For example, in Germany, where our study firm is based, at least one large firm announces cuts of more than 800 jobs on each third working day of the year (Friebel and Heinz, 2014). It is often a painful experience for workers. Indeed, most of the literature on the effects of downsizing on individual outcomes (attitudes, perceptions, workplace behaviors) finds negative effects for both victims and survivors (Luthans and Sommer, 1999; Allen et al., 2001; Brockner et al., 2004; Gilson et al., 2004; Travaglione and Cross, 2006; Trevor and Nyberg, 2008). Yet, the research findings on its firm-wide consequences (sales, productivity, financial indicators) are more equivocal, with some studies finding a negative link between downsizing and subsequent firm performance (De Meuse et al., 1994, 2004; Guthrie and Datta, 2008; Goesaert et al., forthcoming) and others positive (Espahbodi et al., 2000; Wayhan and Werner, 2000; Baumol et al., 2003; Siegel and Simons, 2010).

In their survey of the downsizing literature, Datta et al. (2010) discuss several reasons for the differences in the firm-wide effects of downsizing, among which are differences in the definitions of downsizing (self-reported vs. press announcements vs. employment drop beyond a certain threshold); in the theoretical approaches to modelling its effect (the direct vs. mediated effect); in the statistical method to estimate it (causality vs. association); and in the context in which downsizing takes place. Focussing on the context, downsizing is found to have a more positive (less negative) effect on performance when i) there is organizational slack, ii) downsizing is done proactively rather than in response to a performance dip (Love and Nohria, 2005), iii) downsizing is coupled with organizational redesign (Friebel et al., 2014), iv) downsizing is perceived as being forced upon the firm by external contingencies rather than initiated internally (Drzensky and Heinz, forthcoming), and v) certain HR inputs 
are in place, such as supervisor support and distributive justice (Brockner et al., 2004; Spreitzer and Mishra, 2002), adequate communication and benefits provision (Chadwick et al., 2004), and high-involvement work practices (Zatzick and Iverson, 2006). ${ }^{1}$

This paper addresses the importance of context by examining the role of unwritten social norms and obligations between the workers and the firm as well as within a worker team, collectively referred to as "psychological contract” (Levinson et al., 1962; Rousseau, 1989), in shaping the performance effects of downsizing. The breach of psychological contract has been recognized as one of the reasons why downsizing negatively affects individual worker performance (Robinson, 1996; De Meuse et al., 2004); however, little is known about firm-wide effects of downsizing that occur through the violation of different psychological contracts.

Using unique data from a German retail chain undergoing major restructuring, we estimate the effect of downsizing announcements on current sales in the two contexts: i) store closure and ii) store sale to another firm. In terms of psychological contract violation, store sale versus closure are two different downsizing contexts indeed, because different psychological contracts are terminated when a store is to be closed and when it is to be sold. When a store is to be sold to another firm, the workers change their employer but probably keep their job in the same shop (layoffs by new owners are unlikely, see the study context section) and hence their team. Thus, while the psychological contract between the firm and the workers in a sold shop is disrupted, the one within the worker team in that shop is preserved. When a store is to be closed down, however, the workers are either relocated to other stores within our study firm or lose their jobs. Thus, in addition to the psychological contract between the firm and the workers being terminated, the one within the worker team is

\footnotetext{
${ }^{1}$ To be precise, the finding in Zatzick and Iverson (2006) is that the consequences of downsizing are worse in workplaces with a greater use of high-involvement work practices (HIWP) (team-based learning and incentives, information exchange); at the same time, firms that continue supporting their HIWP during downsizing suffer less.
} 
discontinued as well. Moreover, the heightened risk of unemployment faced by the workers in a store to be closed may have an additional effect on performance. Summing up, the announced downsizing would have a negative effect on current sales, and this effect would be stronger in the stores to be closed than in the stores to be sold.

In what follows, we develop the above intuition into testable hypotheses which we build based on the existing literature and our study firm's specific circumstances. We then explain how we use the particulars of the restructuring procedure in our study firm to identify the impact of downsizing on store sales from the variation in the timing of downsizing announcements. We present our empirical results and discuss them in connection to our study hypotheses and the existing literature. Finally, we summarize our contributions to the literature on downsizing, outline the implications of our results to management practice, list the limitations of our study known to us, and conclude.

\section{LITERATURE REVIEW}

In this section, we build on Datta et al.'s (2010) and Datta and Basuil's (2015) surveys of downsizing literature to place psychological contract within the downsizing literature and identify research gaps that we can cover.

\section{Individual and firm-wide consequences of downsizing}

The literature finds a negative effect of downsizing on individual workers' attitudes (job satisfaction, commitment, involvement, motivation), perceptions (supervisor support, justice), workplace behaviors (turnover and absenteeism), and individual work performance. Starting with attitudes and perceptions, downsizing was found to be negatively linked to survivors' job involvement, commitment and satisfaction (Luthans and Sommer, 1999; Allen et al., 2001; Brockner et al., 2004; Gilson et al., 2004). Downsizing was also found to negatively affect 
perceived supervisor support (Amabile and Conti, 1999; Luthans and Sommer, 1999) and to increase the likelihood of conflict in the workplace (Gilson et al., 2004).

Among the workplace behaviours affected by downsizing, turnover intentions and absenteeism are most frequently studied. Trevor and Nyberg (2008) found a positive correlation between voluntary turnover and layoffs through downsizing on the sample of “employee friendly companies”, which was mitigated by higher organizational commitment. Travaglione and Cross (2006) found an increase in survivor absenteeism followed by a downsizing, but no effect of downsizing on turnover intentions.

Turning to individual work performance, negative correlations are found between downsizing and creativity (Amabile and Conti, 1999), willingness to provide effort (Brockner et al., 1992; Brockner et al., 1993; Brandes et al., 2008), and general self-reported job performance (Armstrong-Strassen and Schlosser, 2008). A related literature investigates the consequences of downsizing for individual effort through experiments in which groups of participants perform real-effort tasks before and after one of the group members is removed (this proxies the downsizing event). Examples include Brockner et al. (1987), who find a negative effect of downsizing on survivors' task performance, and Drzensky and Heinz (forthcoming), who also find a negative effect, but only when the decision to downsize is made by the group leader rather than the experimenter.

With downsizing negatively affecting a wide range of individual outcomes, one might expect the same effect on firm-wide outcomes. However, firm-wide effects of downsizing are much less uniform. For instance, among the more recent studies measuring the effect of downsizing on firm financial performance (sales, labor and total factor productivity, return on assets) positive effects are reported in Espahbodi et al. (2000), Wayhan and Werner (2000) and Baumol et al. (2003) on the samples of large firms in U.S. that publicly announced workforce reductions; in Yu and Park (2006) and Siegel and Simmons (2010) on a broader 
samples of South Korean and Swedish firms; in Atanassov and Kim (2009) on a still broader sample of about 25,000 firms in 41 countries; and in Friebel et al. (2014) on the performance data from U.S. railroad operators. At the same time, downsizing was found to negatively affect organizational performance in De Meuse et al. $(1994,2004)$ who measured profit margins and return on assets in the Fortune 100 firms that did and did not lay off workers; in Guthrie and Datta (2008) who compared return on assets in the downsized vs. non-downsized U.S. firms; and in Goesaert et al. (forthcoming) who looked at the effect of downsizing on productivity in 500 largest German firms. Much of the research, including ours, estimate the immediate effect of downsizing; but the few studies looking at medium- to long-term effects of downsizing still disagree. In the years after downsizing, improvement in firm performance is found in Cascio et al., (1997), and recovery (but not improvement) in Cascio and Young (2003), De Meuse et al. (2004) and Goesaert et al. (forthcoming).

\section{The importance of downsizing context}

Several reasons have been proposed for the differences in the firm-wide effects of downsizing (Datta et al., 2010, pp. 337-340), among which are differences in the definitions, theories and empirical frameworks, as well as in the context in which downsizing occurs. The differences in downsizing context, on which we focus here, are important because the firm-wide effect of downsizing reflects the balance between the gains in operational efficiency and the losses in worker morale. Contextual factors affect one or both parts of this balance. For instance, downsizing done to reduce slack would bring more efficiency gains than when it is done in already lean organizations responding to a worsening in the market conditions (Love and Nohria, 2005). Similarly, the gains from downsizing coupled with a broader firm restructuring are larger than the gains from downsizing alone (Friebel et al., 2014). 
Holding the efficiency gains constant and turning to worker morale, downsizing is found to be less detrimental when support is available throughout the process and justice perceptions are sufficiently high (Brockner et al., 2004, Chadwick et al., 2004), and when the firm managers can distance themselves from the decision to downsize. The latter finding is reported in Drzensky and Heinz (forthcoming) who set up a lab experiment in which “employees” did a real-effort task in groups headed by an "employer” who would benefit from their effort. In the treatment condition, employers would receive extra money for dismissing one randomly picked employee in their group if they chose to do so (half of the employers did). In the control condition, employers had no such choice: the decision to dismiss or keep an employee was made by the experimenters at random. While the “surviving” employees' effort in the control condition was unaffected by the dismissal of their group mates, those in the treatment groups reduced their effort by 43 percent as compared to their baseline performance.

\section{Downsizing and psychological contract}

Why would effort reduction differ depending on the manager's involvement in the decision to downsize? Drzensky and Heinz (forthcoming) argue that the employees in the treatment condition of their experiment interpreted the employer's decision as a signal of the employer's type 2 : "selfish”, if the employer decides to dismiss an employee, or "altruistic", if not. The employer's type, revealed through his decision, carries information about the obligations that she or he is prepared to take as part of the informal employer-employee relationship. The employees’ effort response varies according to these perceived obligations.

The presumed mutuality of obligations in the employer-employee relationship is captured in the concept of psychological contract, defined as “an individual's belief regarding

\footnotetext{
${ }^{2}$ A survey article by Connely et al. (2011) is a good introduction to the signalling theory and its applications in management research.
} 
the terms and conditions of a reciprocal exchange agreement between that focal person and another party” (Rousseau, 1989, p. 123). Given the importance of the promise of stable employment made in the employer-employee psychological contract, the breach of this promise through downsizing has been viewed as a violation of psychological contract by the firm and was found to result in lower performance from worsening employee attitudes and effort withdrawal (Robinson, 1996; De Meuse et al., 2004). Predictably, employee behavioral reactions to the breach of psychological contract through downsizing are found to vary with perceived job insecurity and intrinsic motivation for the job (Conway et al., 2014).

Literature identifies different dimensions of psychological contract, distinguishing between transactional vs. relational and vertical vs. horizontal contracts. Transactional contracts cover material aspects of an employment relationship, such as pay, working conditions and formal procedures, whereas relational contracts are characterized by employees' obligation of loyalty in exchange for the employer's obligation of job security (Rousseau, 1990). Vertical psychological contracts involve some definition of authority; for example, a psychological contract between employees and employers is a vertical one. Horizontal contracts, on the other hand, exist between individuals of equal hierarchical status (Sverdrup, 2012; Sverdrup and Schei, 2013). Another dimension of psychological contract discussed in the literature refers to the circumstances under which a psychological contract fails. Rousseau (1995, p. 112) classifies these circumstances into three groups: reneging, when the contract is intentionally breached; inadvertent violation, when there is a misunderstanding of the terms of a contract; and disruption, when the employer is unable to fulfil its obligations due to economic or environmental factors beyond its control. ${ }^{3}$ Yet, despite the variety of dimensions of psychological contract, its applications in downsizing research are limited to viewing downsizing as a violation of the vertical psychological

\footnotetext{
${ }^{3}$ Morrison and Robinson (1997) conceptualize reneging and inadvertent violation (or "incongruence" in their terms) as two distinct initial states of the process leading up to psychological contract violation.
} 
contract by the employers, often without specifying the circumstances in which the contract is violated: reneging, inadvertent violation or disruption, to borrow the terminology above.

\section{Research gaps}

Our review of the downsizing literature points out to three relatively under-researched areas where our study contributes. First, there is little research on the consequences of downsizing through the violation of horizontal psychological contracts. Such violations are likely to occur when entire workplaces are discontinued or reorganized as part of the downsizing process, without preserving worker teams. Second, owing to a lack of data, it is often impossible to distinguish between the different circumstances of psychological contract violation. Yet, such circumstances are important, since they affect employees’ perception of the employer's type and its motives for downsizing, leading to different behavioral reactions to the event. Third, most of the downsizing literature is concerned with either individual or firm-wide outcomes of downsizing, omitting workplace-level outcomes. Datta et al.'s (2010) survey mentions only one workplace-level study, Mishra and Mishra (1994), who surveyed of managers of 91 business units in 43 firms that went through downsizing in the past, finding that downsizing negatively affects perceived performance of the workplace. (There are no workplace-level studies in the more recent review by Datta and Basuil, 2015.) In the next sections, we apply our in-depth knowledge of the downsizing circumstances in our study firm and its unique data to produce evidence that helps bridge these gaps.

\section{STUDY CONTEXT AND HYPOTHESES DEVELOPMENT}

We develop our testable hypotheses based on the existing literature, surveyed above, as well as particular circumstances of our study firm. These circumstances are crucial for 
characterizing downsizing through sale and closure in terms of violation of different psychological contracts; hence, we carefully present them in what follows.

Our study firm is a part of a large groceries retailer in Germany. It operates a network of 193 small bakeries and a central production facility from which prefabricated bread is delivered to the bakeries. Our analysis covers the retail part of the business, which employed around 1,400 sales assistants during our study period.

The sales assistants are mainly female workers (93\%) aged 35-40, 90 percent of whom work part-time. An average bakery shop employs seven sales assistants. They are managed by a shop supervisor who reports to an area manager in charge of 10-15 shops, who in turn reports directly to the headquarters. Owing to technological reasons, sales assistants cannot specialize in particular tasks; instead, they must constantly coordinate, exchange tasks, and help each other. Accordingly, teamwork and mutual help are the central elements of the horizontal psychological contract. Informal sanctions would follow after refusing to replace a colleague or failing to clean up after the end of the shift.

There is minimal career progression and limited training opportunities for sales assistants; however, compensating for these disadvantages is a culture of employment stability with hardly any worker ever being laid off. This culture is reinforced by a powerful worker council that by German law had to agree to all company decisions deemed to significantly affect the welfare of its workers. Indeed, our conversations with the firm management, sales assistants and their representatives in the workers council suggest that the promise of stable employment is the key element in the vertical psychological contract between the firm and its workers.

In the preceding decades, the firm had successfully developed its business model exploiting the benefits of attractive locations of its bakeries, such as supermarkets and malls, as well as economies of scale thanks to centralized production of prefabricated bread. In 2011, 
however, discounter retailers Aldi and Lidl began to sell freshly baked bread in their dense network of existing shops, with large success. Their bread is regarded to be equally good as that in the bakery chains, but is sold at much lower prices. Thus, the discounters have literally eaten into the bakeries' market share. Forced by the mounting competitive pressure, after several attempts to improve sales, ${ }^{4}$ its parent company decided to restructure our study firm. It was decided that the firm should concentrate on production and that its bakery shops would be integrated into the parent company's retail operations as of January 2015. As part of this integration, the management of our firm was instructed to downsize by selling or closing down relatively underperforming shops until December 2014. Past performance was explicitly stated as the only criterion for downsizing. In Spring 2014, the managers tasked with downsizing came up with a list of 57 shops to be sold or closed down. This list was kept secret to prevent an anticipated negative response by employees.

The timing of the restructuring procedure was as follows. Our study firm made a general announcement of the restructuring in early June 2014, mentioning that some shops will be discontinued until the year-end, but no individual shops were informed then. Starting from Spring 2014, the managers were in talks with potential buyers of the shops to be discontinued. After the sale of a shop was agreed, and four weeks before the actual takeover date, the employees of that shop were informed by their district manager about their shop being sold to a new owner.

It is important to note that the sale of a store was unlikely to put existing jobs in jeopardy. First, the new owner of each sold store had to continue the employment contracts of the existing employees as part of the sale agreement. That is, no employee could legally be laid off before the end date of their contract. Second, with the uniformly high operational efficiency, homogenous production technology and low profit margins, all of which is

\footnotetext{
${ }^{4}$ The study firm attempted to improve sales through various promotional activities, training, hiring more highlyskilled workers, and introducing team bonus for its sales assistants (Friebel et al., 2015).
} 
characteristic of the German retail bakery business, there was little slack to begin with. Therefore, borrowing Rousseau's (1995) terminology, downsizing by selling a store to another firm would disrupt the vertical psychological contract between our firm and its employees in that store. Also, since no jobs would be shed after the sale of a store, preserving its worker team, downsizing through sale would not affect the horizontal psychological contract within the team.

The shops that could not be sold were closed down. Again, the employees in those shops were informed that their shops would be closed down four weeks before the closure date. Most employees in the shops to be closed down were offered jobs elsewhere in the firm, but the original teams could not be preserved and many workers did not accept their new jobs and left. With all the workers in the closing stores having to relocate or leave and seeing their teams disintegrate, downsizing through store closure implies the firm's reneging on its vertical psychological contract with the workers as well as the disruption of the psychological contract within the affected teams.

In sum, the particulars of the restructuring procedure in our study company make it possible to study the consequences of downsizing in terms of violation of vertical and horizontal psychological contracts. Thus, we are able to observe the episodes of downsizing through sale, in which case the vertical psychological contract is disrupted and the horizontal psychological contract preserved, as well as downsizing through closure, in which case the vertical psychological contract is reneged and the horizontal one disrupted. Since a psychological contract, vertical or horizontal, is violated when a store is either sold or closed, we expect a negative effect of announced downsizing. Hence we propose

Hypothesis 1: Downsizing announcement will negatively affect current sales in the store in question. 
Because the event of downsizing through sale violates one (vertical) psychological contract, whereas downsizing through closure violates both vertical and horizontal contracts, we expect its performance consequences to be more severe. Hence our

Hypothesis 2: The negative effect of downsizing on workplace performance will be stronger when the workplace is shut down than when it is sold to another owner.

\section{DATA AND METHOD}

\section{Data description}

We use individual and shop-level data. The shop-level data include monthly sales and customer visits calculated from cash-till records for the period between January 2012 and December 2014, as well as mystery shopper reports (until May 2014) and firm records indicating whether a shop was sold or closed down, and when. The individual data contain hours worked and employment contract status (temporary or permanent) running from January 2012 up to June $2014 .{ }^{5}$ Additionally, we use the data from employee questionnaire which we ran in late May 2014, some days before restructuring was announced, as part of another research project. The variables we measured in the survey were i) overall job satisfaction, constructed following van Dick et al.'s (2001) translation of the original items in Hackman and Oldham (1980); ii) organizational commitment using the metrics developed by Allen and Meyer (1990); and iii) reciprocity as measured in Dohmen et al. (2008). We also separately measured satisfaction with colleagues and frequency of meeting colleagues in private, in order to learn about the strength of connections within teams in different shops. The survey questionnaires were distributed through the district managers and collected by our

\footnotetext{
${ }^{5}$ We do have some personnel records dated beyond June 2014 when the restructuring started. However, because of intensified movement of workers from the bakeries to production facility or to the parent company during the restructuring period, we cannot distinguish between the employees who quit (voluntary or otherwise) and those who moved within the firm and its parent company. The incompleteness of our personnel records past June 2014 renders them too "noisy" for use in our analysis.
} 
research assistants in sealed envelopes as an extra guarantee of anonymity. Our logistics and communication efforts helped secure a response rate of 65 percent.

\section{Descriptive statistics}

Table 1 reports descriptive statistics for all shops together and for the continuing and discontinued shops separately for the period between January 2012 and May 2014, before the restructuring was announced firm-wide. It shows that discontinued shops had already lower sales and customer visits, and were smaller and less productive before the restructuring started. Especially lagging are the 14 shops that ended up being closed down. This nonrandom selection of shops to be discontinued reflects the vision of the company management which was to improve efficiency by ridding themselves of relatively inefficient shops. As sales exhibit considerable inertia, we control for the pre-existing differences in sales between continuing and discontinued shops (see the next section). At the same time, there are no differences between other shop attributes, such as mystery shopping scores, average share of workers with a permanent contract, and employee attitudes averaged by shop.

[Insert Table 1 here.]

Table 2 shows how many shops were taken over by new owners or closed in each month during the restructuring period. A total of 43 shops were sold and 14 closed down. Typically, a takeover or a closure happened at the end of the month, so the announcement would be made in the beginning of the month. ${ }^{6}$ Although two-thirds of the shops on the discontinuation list were sold as of July 2014, their takeover dates varied between June and December 2014 depending on the new owners' circumstances. Hence, the variation in the dates of the sale announcement to the employees in the shop in question, which preceded the takeover date by one month, is quasi-random with respect to the characteristics of the shops

\footnotetext{
${ }^{6}$ In a few cases a shop was sold or closed in the middle of the month. Since we use monthly data, we extrapolated the monthly sales in the discontinued shops by dividing the actual sales by the share of the month the shop was operating.
} 
that were sold. It is this variation that we use to identify the causal effect of downsizing on sales.

[Insert Table 2 here.]

Table 2 also shows that most of the shops that ended up being closed were shut down in the end of 2014, after unsuccessful attempts to sell them. There is less variation in the dates of the shop closure announcements. Yet, because they all had to be closed down before the restructuring deadline (end of December 2014), the dates of their closure (November or December 2014 in 11 out of 14 cases) are unlikely to depend on their characteristics. Again, we use the variation in the dates of shop closure announcement to identify its effect on sales.

[Insert Figure 1 here.]

What happened to sales in the shops that were to be sold or closed? Figure 1 plots log differences between the average sales in the discontinued and continuing shops up to six months before the employees in the discontinued shops were notified. As we have already seen in Table 1, the discontinued shops, especially the ones that were closed down, were selling less to begin with. The log difference in sales is fairly stable until the month when the announcement was made, suggesting no anticipation effects (still, we control for them statistically, see next section). In the month of the announcement, sales plunge by 6 and 24 percent in the sold and closed shops, respectively, as compared to the average difference in sales up to one month before the announcement. The drop in sales after the downsizing announcement is a first indication for the effect it may have had on sales. In the next sections, we explain how we estimate this effect more carefully, controlling for other factors that may affect sales, and present our estimation results. 


\section{Estimation procedure}

The simplest specification one could use to estimate the differences in sales between the continuing and discontinued shops is

(1) $y_{i t}=\alpha+\beta * D_{i t}+\gamma * L_{i t}+u_{i t}$

where $y_{i t}$ is the $\log$ sales of shop $i$ in month $t, D_{i t}$ is the discontinuation dummy equal 1 if a shop receives the discontinuation announcement in month $t$ and 0 otherwise, $L_{i t}$ is $\log$ total hours worked, and $u_{i t}$ is the error term.

Specification (1) will give a biased estimate of the effect of our interest if the decision whether to discontinue a shop or not depends on its past performance, in which case part of the estimated effect of discontinuation announcement will be due to factors that determined past sales. Indeed, we learned from the interviews with the company management that their decision on which shops to discontinue was solely based on the shops’ past sales performance. Therefore, to control for the correlation between past sales and the decision to discontinue, we add lags of sales for up to five month, estimating

(2) $y_{i t}=\alpha+\beta * D_{i t}+\sum_{j=1}^{5} \delta_{j} * y_{i t-j}+\gamma * L_{i t}+u_{i t}$

Another important factor is seasonality in sales, which we control for by adding month dummies in the previous specification:

(3) $y_{i t}=\alpha+\beta * D_{i t}+\sum_{j=1}^{5} \delta_{j} * y_{i t-j}+\gamma * L_{i t}+\tau_{t}+u_{i t}$

We further augment specification (3) with leads of the downsizing dummy $D_{i t}$ to control for possible anticipation effects on sales up to five months before the downsizing is announced in a given shop:

(4) $y_{i t}=\alpha+\sum_{j=0}^{5} \beta_{j} * d_{i t+j}+\sum_{j=1}^{5} \delta_{j} * y_{i t-j}+\gamma * L_{i t}+\tau_{t}+u_{i t}$ 
Controlling for anticipation effects is potentially important because past performance is the main criterion for downsizing, and though it was never communicated as such, employee expectations may have affected their performance before the announcement was made.

Lastly, since past sales may not in fact be the only criterion for downsizing, and because the value of a shop to potential buyers may not be fully captured by past sales, we strengthen the identification of the effect of our interest by adding shop fixed effects:

(5) $y_{i t}=\alpha_{i}+\beta * D_{i t}+\sum_{j=1}^{5} \delta_{j} * y_{i t-j}+\gamma * L_{i t}+\tau_{t}+u_{i t}$

Shop fixed effects control for shop-specific unobserved factors (for instance, location or shop management quality) which may also have affected the decision to discontinue and/or the attractiveness of the shop to potential buyers. It is specification (5) for which a variation in the timing of shop takeover or closure is crucial, since if all shops were taken over or closed down in the same month the downsizing effect $\beta$ could not be identified separately from seasonal $\left(\tau_{t}\right)$ or shop fixed effects $\left(\alpha_{i}\right)$. Since, controlling for past sales and shop-specific unobservables, the variation in the timing of downsizing is quasi-random with respect to shop characteristics, the effect of downsizing on sales that it identifies is plausibly causal.

\section{RESULTS}

\section{Baseline results}

Table 3 presents the regression results from specifications (1) - (5) on the effect of a shop discontinuation announcement (sale or closure) on sales. The coefficient -0.325 on the discontinuation announcement in specification (1) suggests a 28 percent $\left(=e^{-0.325}-1\right)$ drop in monthly sales concurrent with this announcement, which, given the non-random selection of shops into being discontinued, is an overestimate reflecting the fact that the discontinued shops were already selling less. Specification (2), which controls for shop sales history and hence the likelihood of being discontinued, gives a lower estimate of 10 percent. This 
estimate is robust to the inclusion of other controls, such as time dummies (specification 3), leads of the discontinuation dummy (specification 4) and shop-specific fixed effects (specification 5), and is highly statistically significant. The robustness of the estimates of the effect of discontinuation announcement on sales in specifications 3 to 5 implies that past sales is indeed the only critical factor in the discontinuation decision. The finding of a marked decrease in sales by around 10 percent in response to the discontinuation announcement supports our hypothesis 1 . The coefficients on the leads of the discontinuation dummy are small in magnitude and insignificant statistically (their $p$-value is at most 0.13 ). ${ }^{7}$ Thus, information leakages or employee expectations have little effect on sales.

[Insert Table 3 and Table 4 here.]

We now evaluate our hypothesis 2 that distinguishes between the effects of discontinuation through closure and sale. We run specifications (3) - (5) on the same data but now allow for the sale and closure dummies, as well as their leads, to enter separately. The estimation results, reported in Table 4, show that the effect of an announced shop closure $\left.\left(e^{-0.239}-1=-21 \%\right)\right)$ is much larger in magnitude than that of an announced shop sale $(-6 \%)$. As in Table 3, both estimates are robust to specifications and significant, and the effects are localized to the month at the beginning of which the sale or closure announcements were made. Hence, our hypothesis 2 - the effect of closure is stronger than the effect of sale — is supported by the data.

\section{Moderating factors in the effect of downsizing on sales}

In this section we investigate whether the baseline employee attitudes and the risk of unemployment as a result of downsizing moderate its effect on sales. The employee attitudes measured in our survey prior to the firm-wide restructuring announcement and aggregated up

\footnotetext{
${ }^{7}$ The first lead has a relatively large coefficient, though still small compared to the main effect. It is borderline significant presumably because the discontinuation announcement was made sometime in the preceding month in the few cases when shops were discontinued in the middle of the next month.
} 
to the shop level include job satisfaction, commitment and reciprocity, as well as shop averages of satisfaction with colleagues and frequency of meeting work colleagues in private. We proxy the risk of unemployment with the share of workers on a permanent contract in each shop as of June 2014; the lower the permanent employees' share, the higher is shopaverage risk of unemployment.

Both factors are potentially important in shaping the effect of downsizing. Employee attitudes may reflect the state of psychological contract prior to downsizing, and thus affect the consequences of its violation. The moderating effect of permanent employees' share on the link between downsizing and sales is ambiguous. It may mitigate the negative consequences of downsizing, since permanent employees face much lower unemployment risk than do temporary workers, and will therefore spend less time job searching instead of working (not to mention less stress). On the other hand, temporary workers have psychological contracts that are more limited in scope (Parks et al., 1998; de Jong et al., 2009), and their violation may therefore be less consequential for performance, implying that the share of permanent employees should exacerbate the negative effect of downsizing on performance. Thus, whether the mitigating influence of a greater employment protection afforded to permanent workers will overpower the negative effect of the violation of a deeper psychological contract for these workers is an empirical question.

[Insert Table 5 here.]

Table 5 reports the coefficients on the interaction terms of the sale and closure dummies with standardized (mean=0, standard deviation=1) employee attitudes scores and share of permanent workers based on regression specification (5). With the exception of commitment, which appears to weaken the negative performance effect of shop closure (though not shop sale), the interactions of the downsizing dummies with most of the measures of employee attitudes are small in magnitude as compared to the main effect, and are 
statistically insignificant. Given the relatively few observations of the shops being closed and the absence of a similar effect of commitment for the shops being sold, we do not pursue the commitment-closure interaction further, concluding instead that the effect of downsizing on sales depends little on pre-existing employee attitudes. However, we still control for employee attitudes in the regression of sales on downsizing announcements and derive our statistical inferences from the specification 7 in Table 5 that does so.

Turning to permanent employees' share, there is a borderline-significant negative interaction with the shop sale dummy (-0.019, $p$-value 0.11 , specification 7$)$ and a more powerful negative interaction with the shop closure dummy (-0.105, $p$-value 0.001$)$. Both interactions are economically significant: a one standard deviation (about 20\%) increase in the share of permanent workers is associated with about 10 percent larger effect of downsizing through shop closure and two percent larger effect of shop sale. The strong and uniformly negative interaction of a shop sale or closure with the share of permanent employees suggests that permanent employees have a more comprehensive psychological contract with the firm than do temporary employees, reneging on which contract brings heavier consequences. The negative moderating effect of the share of permanent employees is remarkable because it is so strong as to overpower the positive effect one would expect in the absence of psychological contract.

\section{Mechanisms}

In this section we do additional analyses on our data to understand the employee- and technology-related mechanism(s) through which downsizing announcements affected sales. Starting with technology-related mechanisms, nothing changed in the shop operations and work organization after the announcement. Namely, the staff rotas, opening hours, product range and prices, shop layout and technological routines (baking, cleaning, stock handling, 
etc.) did not change. The stability of operational environment before and after downsizing announcement allows us to narrow down our mechanism search to employee-related mechanisms.

The drop in sales after downsizing announcement may have happened as a result of a reduction in customer traffic or/and a decrease in sales per customer visit. To examine the first possibility, we rerun our analysis with the customer visits per shop per month as the dependent variable. Unfortunately, owing to an increased administrative load on our contact in the company's HR department during the restructuring period, we were able to receive the customer visits data only up to September 2014. There were 24 discontinuation announcements in June to September 2014, 22 of them being sales and two closures. Because of the lack of observations on shop closures, we restrict the analysis in this section to estimating the effect of the shop sale announcement.

Table 6 reports estimation results using specification (5) with the log sales and log customer visits as the dependent variables for the subsample limited to the continuing shops and shops being sold up to, and including, September 2014. The effect of the sale announcement on shops sales $(-4.7 \%)$ is close to that found on the entire sample $(-6 \%)$. The effect on log customer visits is somewhat smaller, -3.7 percent. The coefficient estimates on the leads of downsizing announcement in the log customer visits equation are all small and insignificant, suggesting, as before, no anticipation effects. The effect of downsizing announcement on sales per customer visit, estimated as the difference between the effects on $\log$ sales and log customer visits, is -1 percent; its $p$-value, estimated from the coefficient variance-covariance matrix obtained from estimating the sales and customer visits equations jointly, is 0.13 , which is above conventional significance levels. Thus, much of the effect of downsizing on sales is due to fewer customer visits.

[Insert Table 6 here.] 
With the opening hours and staff rotas unchanged, the decrease in sales owing to lower customer traffic must be due to fewer customers being served per unit of time. The decrease in customer traffic could be due to less friendly customer service or lower employee effort. The first possibility - less friendly customer service - is unlikely because, as Friebel et al. (2015) find, proactive sales behavior and friendliness are uncorrelated with sales in our study firm. ${ }^{8}$ Thus, the remaining reason for the lower customer traffic is lower employee effort. Higher absenteeism and lower effort of employees who turned up for work may both contribute to the lower total effort. Friebel et al. (2015) argue that employee effort and customer visits are positively linked through harder-working sales assistants reducing customer queues at peak times. Turning to absenteeism, although we could not obtain the hard data, several district managers in our study firm complained of more employees not showing up for work in the discontinued shops after the sale or closing announcement. This anecdotal evidence is consistent with the results in Travaglione and Cross (2006) who found an increase in absenteeism in the times of downsizing.

\section{DISCUSSION AND CONCLUSION}

Let us summarize our results and weave them into the relevant literature. We have used unique data from a retail network undergoing downsizing through sale or closure of some of its shops over the period of six months. Our empirical method utilizes the knowledge of the specific policies implemented in our study firm to support the downsizing process. We know the criterion for a shop to be sold or closed; namely, past performance, which we also observe. We also know the circumstances of shop sale and closure: shops that the firm managed to sell were taken over by new owners at their convenience, and those that could not be sold were closed down. In both cases, sale or closure, and conditional on their past sales,

\footnotetext{
${ }^{8}$ Given the nature of the product sold in the stores - inexpensive prefabricated bread - customer service quality is less important relative to service speed, which is a function of effort alone.
} 
the timing of downsizing announcement was independent of the shops' current performance. Hence, we argue, the variation in the timing of downsizing was quasi-exogenous.

Our main finding is that discontinuation announcement results in a 10 percent drop in sales on average. This finding is consistent with the oft-reported result that workplace performance decreases following downsizing (Mishra and Mishra, 1994; Brockner et al., 2004; Drzensky and Heinz, forthcoming). Our second finding is a stronger effect of downsizing in shops being closed down (-21\%) than in shops being sold (-6\%). This finding highlights the importance of downsizing context (Datta et al., 2010). More precisely, thanks to our focus on the workplaces sharing the same technology, brand and management, we can identify, and test the effect of, the variations in the context characterized by psychological contract violation. Thus, we characterize downsizing through sale as the event when vertical psychological contract is disturbed and horizontal preserved, and downsizing through closure as the event in which vertical psychological contract is reneged and horizontal is disturbed. The large difference in the effects of downsizing announcement between those two groups of events implies that psychological contract configurations and the circumstances of their violation matter for performance (Robinson, 1996; Morison and Robinson, 1997; De Meuse et al., 2004).

Our third finding is that the effect of downsizing is magnified by the share of permanent workers in the discontinued shops. It highlights the importance of psychological contract in shaping the effect of downsizing relative to other powerful determinants such as unemployment risk, proxied as the share of employees on a permanent contract. Indeed, if psychological contracts did not matter or were not violated by downsizing, or if all workers had the same psychological contract, one would expect the interaction between downsizing and the share of permanent employees to have the positive sign, since better protection from unemployment enjoyed by permanent workers would partially offset the negative first-order 
effect of downsizing. Finding the opposite effect implies that psychological contract i) matters for performance, ii) is violated by downsizing, and iii) differs between permanent and temporary workers.

Finally, we find that lower customer traffic is responsible for much of the drop in sales that follows the downsizing announcement. This finding contributes to the literature on downsizing by shedding some light on the mechanisms behind its effect on performance. Our evidence suggests that much of the drop in sales occurred through serving fewer customers rather than selling less per customer visit. Interestingly, given the neutrality of the effect of downsizing to baseline employee attitudes, our proposed explanation seems to be mechanical rather than behavioral.

Our research makes three other contributions. First, we put a price tag on downsizing by finding its effects on objectively measured workplace performance, thus complementing the research using hard to quantify self-reported performance indicators (e.g. Brockner et al., 1992; Armstrong-Strassen, 2008) or firm-wide accounting measures (e.g. De Meuse et al., 1994; Guthrie and Datta, 2008) which reflect indirect consequences of downsizing such as severance payments and stock market sentiments.

Second, by focussing on workplace performance our research helps bridge the gap between the literatures on individual and firm-wide consequences of downsizing. Covering this gap is important because there is often no direct link between individual and firm-wide performance outcomes; rather, the individual translates into the firm-wide through teams operating at the workplace level, where strategic group behavior and effort complementarities intermediate. The large difference in the downsizing effects when teams are preserved (shop sale) and destroyed (shop closure) shows the importance of the team in translating individual behavioral reactions to downsizing into its firm-wide consequences. 
Third, the effects we find are much closer to causal than studies that use crosssectional survey data could manage to obtain, thus addressing one limitation of the extant research on downsizing (Datta et al., 2010, p. 339). In fact, one way to interpret our study results is to look at them as outcomes of a quasi-experiment where, conditional on past performance, the timing of downsizing announcement varied with the new owners' wishes, and thus independently of shop unobservables. Obtaining causal evidence on the effect of downsizing is essential for informing management practices in firms undergoing downsizing. Informed by our results, managers in charge of downsizing could contain the ensuing losses by preserving teams in the workplaces to be discontinued to the fullest possible extent. A quick closure is not always the best loss containment strategy; in fact, it might be better to incur some monetary loss by selling a shop at a discount rather than closing it down.

The limitation one faces when using field rather than lab data is having to deal with incomplete information on the mechanisms behind the effects of one's interest. While it is clear that sales dropped largely because of fewer customer visits, we have only anecdotal evidence with which to apportion the drop in customer visits to lower effort and higher absenteeism. Future research should use administrative data within firms to obtain more precise results on the importance of these mechanisms. 


\section{REFERENCES}

Allen NJ, Meyer JP. 1990. The measurement and antecedents of affective, continuance and normative commitment to the organization. Journal of Occupational and Organizational Psychology 63 (1): 1-18.

Allen TD, Freeman DM, Russell JEA, Reizenstein RC, Rentz JO. 2001. Survivor reaction to organizational downsizing: Does time ease the pain? Journal of Occupational and Organizational Psychology 74: 145-164.

Amabile TM, Conti R. 1999. Changes in the work environment for creativity during downsizing. Academy of Management Journal 42: 630-640.

Armstrong-Strassen M, Schlosser FK. 2008. Taking a positive approach to organizational downsizing. Canadian Journal of Administrative Science 25: 93-106.

Atanassov J, Kim H. 2009. Labor and corporate governance: International evidence from restructuring decisions. Journal of Finance 64(1): 341-374.

Baumol WJ, Blinder AS, Wolff EN. 2003. Downsizing in America: Reality, Causes, and Consequences. Russell Sage Foundation: New York.

Brockner J, Sprietzer G, Mishra A, Hochwarter W, Pepper L, Weinberg J. 2004. Perceived control as an antidote to the negative effects of layoffs on survivors' organizational commitment and job performance. Administrative Science Quarterly 49: 76-100.

Brockner J, Grover S, Reed T, DeWitt R, O’Malley M. 1987. Survivors’ reaction to layoffs: We get by with a little help from our friends. Administrative Science Quarterly 32(4): 526541.

Brandes P, Castro SL, James MSL, Martinez AD, Matherly TA, Ferrris GR. 2008. The interactive effects of job insecurity and organizational cynicism on work effort following a layoff. Journal of Leadership and Organizational Studies 14: 233-247.

Brockner J, Grover SL, O’Malley MN, Reed TF, Glynn MA. 1993. Threat of future layoffs, self-esteem, and survivors' reactions: Evidence from the laboratory and the field. Strategic Management Journal 14: 153-166.

Brockner J, Grover SL, Reed TF, DeWitt RL. 1992. Layoffs, job insecurity and survivors' work effort: Evidence from an inverted-U relationship. Academy of Management Journal 35: 413-425.

Cascio WF, Young CE, Morris JR. 1997. Financial consequences of employment-change decisions in major U.S. corporation. Academy of Management Journal 40: 1175-1189.

Cascio WF, Young CE. 2003. Financial consequences of employment change decisions in major US Corporations, 1982-2000. In Resizing the Organization: Managing Layoffs, Divestitures and Closings. De Meuse K, Marks M (eds). Jossey-Bass: San Francisco, CA; 131-156.

Chadwick C, Hunter LW, Walston SL. 2004. Effects of downsizing practices on the performance of hospitals. Strategic Management Journal 25: 405-427.

Connelly BL, Certo ST, Ireland RD, Reutzel CR. 2011. Signaling Theory: A review and assessment. Journal of Management 37(1): 39-67.

Conway N, Kiefer T, Hartley J, Briner RB. 2014. Doing more with less? Employee reactions to psychological contract breach via target similarity or spillover during public sector organizational change. British Journal of Management 25: 737-754. 
Datta DK, Guthrie JP, Basuil D, Pandey A. 2010. Causes and effects of employee downsizing: A review and synthesis. Journal of Management 36(1): 281-348.

Datta DK, Basuil D. 2015. Does employee downsizing really work? The empirical evidence. In Human Resource Management Practices, Andersen M, Nowak C (eds). Springer: Switzerland; 197-221.

De Jong J, Schalk R, De Cuyper N. 2009. Balanced versus unbalanced psychological contracts in temporary and permanent employment: Associations with employee attitudes. Management and Organization Review 5(3): 329-351.

De Meuse KP, Vanderheiden PA, Bergmann TJ. 1994). Announced layoffs: Their effect on corporate financial performance. Human Resource Management 33: 509-530.

De Meuse KP, Bergmann TJ, Vanderheiden PA, Roraff CE. 2004. New evidence regarding organizational downsizing and a firm's financial performance: A long-term analysis. Journal of Managerial Issues 16: 155-177.

Drzensky F, Heinz M. (forthcoming). The Hidden Costs of Downsizing. Economic Journal.

Dohmen T, Falk A, Huffmann D, Sunde U. 2008. Representative trust and reciprocity: Prevalence and determinants. Economic Inquiry 46(1): 84-90.

Friebel G, Heinz M. 2014. Media slant against foreign owners: Downsizing. Journal of Public Economics 120: 97-106.

Friebel G, Heinz M, Krüger M, Zubanov N. 2015. Team incentives and performance: Evidence from a retail chain. CEPR Discussion Paper. Available at: http://cepr.org/active/publications/discussion_papers/dp.php?dpno=10796.

Friebel G, McCullogh G, Angullo LP. 2014. Patterns of restructuring: The US class 1 railroads from 1984 to 2004. Journal of Transport Economics and Policy 48(1): 115-135.

Espahbodi R, John TA, Vasudevan G. 2000. The effects of downsizing on operating performance. Review of Quantitative Finance and Accounting 15: 107-126.

Gilson C, Hurd F, Wagar T. 2004. Creating a concession climate: The case of serial downsizers. International Journal of Human Resource Management 15: 1056-1068.

Goesaert T, Heinz M, Vanormelingen S. (forthcoming). Downsizing and firm performance: Evidence from German firm data. Industrial and Corporate Change.

Guthrie JP, Datta DK. 2008. Dumb and dumber: The impact of downsizing on firm performance as moderated by industry conditions. Organization Science 19(1): 108-123.

Hackman JR, Oldham GR. 1980. Work Redesign. Addison-Wesley: Reading, U.K.

Levinson H, Price CR, Munden KJ, Solley CM. 1962. Men, management, and mental health. Harvard University Press: Cambridge, MA.

Love EG, Nohria N. 2005. Reducing slack: The performance consequences of downsizing by large industrial firms. Strategic Management Journal 26: 1087-1108.

Luthans BC, Sommer SM. 1999. The impact of downsizing on workplace attitudes: Differing reactions of managers and staff in a health care organization. Group Organization Management 24: 46-70.

Morrison EW, Robinson SL. 1997. When employees feel betrayed: A model of how psychological contract violation develops. Academy of Management Review 22: 226-257. 
Mishra AK, Mishra KE. 1994. The role of mutual trust in effective downsizing strategies. Human Resource Management 33: 261-279.

Parks JM, Kidder DL, Gallagher DG. 1998. Fitting square pegs into round holes: mapping the domain of contingent work arrangements onto the psychological contract. Journal of Organizational Behavior 19: 697-730.

Rousseau DM. 1989. Psychological Contracts in Organizations: Understanding Written and Unwritten Agreements, Sage Publications: Thousand Oaks, CA.

Rousseau DM. 1995. Psychological contracts in organizations. Sage: Thousand Oaks, CA.

Robinson SL. 1996. Trust and breach of the psychological contract. Administrative Science Quarterly 41: 574-599.

Siegel DS, Simons KL. 2010. Assessing the effect of mergers and acquisitions on firm performance, plant productivity, and workers: New evidence from matched employeremployee data. Strategic Management Journal 31: 903-916.

Spreitzer GM, Mishra AK. 2002. To stay or to go: Voluntary survivor turnover following an organizational downsizing. Journal of Organizational Behavior 23: 707-729.

Sverdrup TE. 2012. The strength of reciprocity: Exploring horizontal psychological contracts in work groups. PhD dissertation.

Sverdrup TE, Schei V. 2013. The power of reciprocity: Horizontal psychological contracts and group functioning. Academy of Management Proceedings (meeting abstract).

Travaglione A, Cross B. 2006. Diminishing the social network in organizations: does there need to be such a phenomenon as 'survivor syndrome' after downsizing? Strategic Change 15: $1-13$.

Trevor CO, Nyberg AJ. 2008. Keeping your headcount when all about you are losing theirs: Downsizing, voluntary turnover rates, and the moderating role of HR practices. Academy of Management Journal 51: 259-276.

van Dick R, Schnitger C, Schwartzmann-Buchelt C, Wagner U. 2001. Der Job Diagnostic Survey im Bildungsbereich. Zeitschrift für Arbeits- und Organisationspsychologie 45(2): 7492.

Van Dierendonck D, Jacobs G. 2012. Survivors and victims: A meta-analytical review of fairness and organizational commitment after downsizing. British Journal of Management 23(1): 96-109.

Wayhan VB, Werner S. 2000. The impact of workforce reductions on financial performance: A longitudinal perspective. Journal of Management 26: 341-363.

Yu G, Park J. 2006. The effect of downsizing on the financial performance and employee productivity of Korean firms. International Journal of Manpower 27(3): 230-250.

Zatzick CD, Iverson RD. 2006. High-involvement management and workforce reduction: Competitive advantage or disadvantage? Academy of Management Journal 49: 999-1015. 
FIGURES AND TABLES

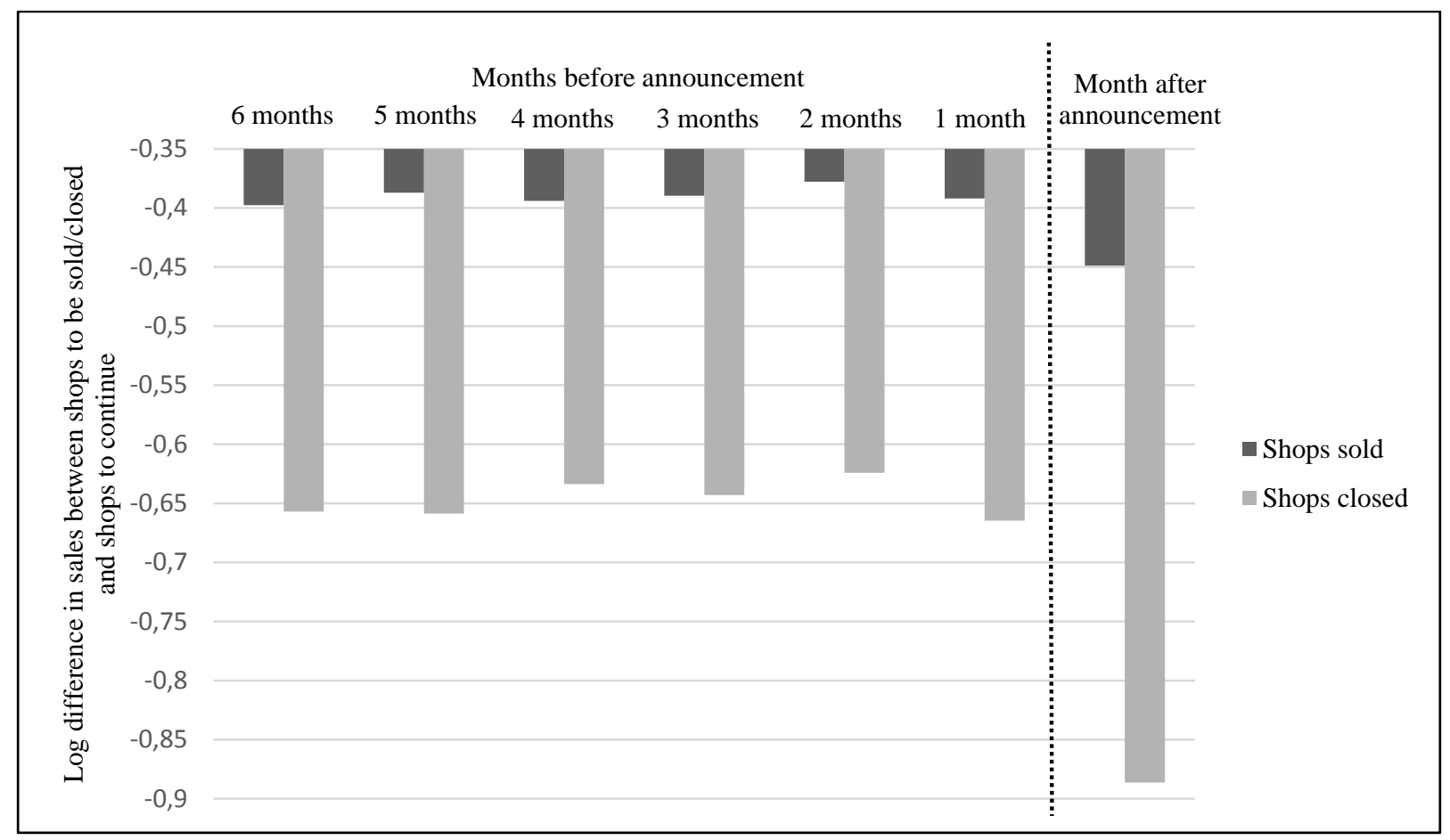

Figure 1: Differences between the average sales in the discontinued and continuing shops before and after the downsizing announcement 
Table 1: Descriptive statistics for all shops before the restructuring was announced in

June 2014

\begin{tabular}{|c|c|c|c|c|c|}
\hline & \multirow{2}{*}{ All shops } & \multirow{2}{*}{ Continuing } & \multicolumn{2}{|c|}{ Discontinued } & \multirow{2}{*}{$\begin{array}{c}\text { P-value t-test } \\
\text { Continuing vs. dis- } \\
\text { continued stores }\end{array}$} \\
\hline & & & Sold & Closed & \\
\hline Number of shops & 193 & 136 & 43 & 14 & \\
\hline Sales & $\begin{array}{c}27,622 \\
(13,031)\end{array}$ & $\begin{array}{c}30,941 \\
(13,568)\end{array}$ & $\begin{array}{l}20,446 \\
(5,711)\end{array}$ & $\begin{array}{l}17,325 \\
(9,172)\end{array}$ & 0.00 \\
\hline Hours worked & $\begin{array}{c}721 \\
(350.0)\end{array}$ & $\begin{array}{c}780 \\
(377)\end{array}$ & $\begin{array}{c}579 \\
(200)\end{array}$ & $\begin{array}{c}583 \\
(265)\end{array}$ & 0.00 \\
\hline Sales per hour worked & $\begin{array}{c}42.5 \\
(55.9)\end{array}$ & $\begin{array}{c}45.5 \\
(66.0)\end{array}$ & $\begin{array}{c}37.2 \\
(11.1)\end{array}$ & $\begin{array}{l}30.1 \\
(9.3)\end{array}$ & 0.00 \\
\hline Number of customers & $\begin{array}{c}9,923 \\
(3,924)\end{array}$ & $\begin{array}{l}11,015 \\
(3,967)\end{array}$ & $\begin{array}{c}7,690 \\
(1,938)\end{array}$ & $\begin{array}{c}6,132 \\
(2,634)\end{array}$ & 0.00 \\
\hline Mystery shopping score & $\begin{array}{c}89.3 \% \\
(11.4 \%)\end{array}$ & $\begin{array}{c}89.3 \% \\
(11.4 \%)\end{array}$ & $\begin{array}{c}89.6 \% \\
(11.1 \%)\end{array}$ & $\begin{array}{l}88.6 \% \\
(11.9 \%)\end{array}$ & 0.21 \\
\hline Overall job satisfaction score & $\begin{array}{c}4.85 \\
(0.98)\end{array}$ & $\begin{array}{c}4.86 \\
(1.03)\end{array}$ & $\begin{array}{c}4.79 \\
(0.89)\end{array}$ & $\begin{array}{c}4.93 \\
(0.76)\end{array}$ & 0.79 \\
\hline Commitment score & $\begin{array}{c}4.46 \\
(0.87)\end{array}$ & $\begin{array}{c}4.51 \\
(0.91)\end{array}$ & $\begin{array}{c}4.28 \\
(0.80)\end{array}$ & $\begin{array}{c}4.54 \\
(0.67)\end{array}$ & 0.24 \\
\hline Reciprocity score & $\begin{array}{c}5.73 \\
(0.73)\end{array}$ & $\begin{array}{c}5.70 \\
(0.73)\end{array}$ & $\begin{array}{c}5.72 \\
(0.76)\end{array}$ & $\begin{array}{c}6.00 \\
(0.64)\end{array}$ & 0.28 \\
\hline Satisfaction with co-workers & $\begin{array}{c}5.58 \\
(1.08)\end{array}$ & $\begin{array}{c}5.65 \\
(1.06)\end{array}$ & $\begin{array}{c}5.42 \\
(1.17)\end{array}$ & $\begin{array}{c}5.40 \\
(0.82)\end{array}$ & 0.33 \\
\hline $\begin{array}{l}\text { Frequency of private } \\
\text { meetings with co-workers }\end{array}$ & $\begin{array}{c}4.87 \\
(1.58)\end{array}$ & $\begin{array}{c}4.76 \\
(1.60)\end{array}$ & $\begin{array}{c}5.34 \\
(1.38)\end{array}$ & $\begin{array}{c}4.62 \\
(1.67)\end{array}$ & 0.10 \\
\hline
\end{tabular}


Table 2: Number of shops that were sold and closed, by the month of the announcement

\begin{tabular}{lcc}
\hline \hline Month of 2014 & Sold & Closed \\
\hline June & 2 & 0 \\
July & 4 & 0 \\
August & 4 & 2 \\
September & 12 & 0 \\
October & 10 & 1 \\
November & 8 & 5 \\
December & 3 & 6 \\
\hline \hline
\end{tabular}


Table 3: The impact of shop sale or closure announcement on sales

\begin{tabular}{|c|c|c|c|c|c|}
\hline Dependent variable: log monthly sales & (1) & (2) & (3) & (4) & (5) \\
\hline SALE or CLOSURE announcement & $\begin{array}{l}-0.325 \\
(0.046)\end{array}$ & $\begin{array}{c}-0.103 \\
(0.021)\end{array}$ & $\begin{array}{c}-0.107 \\
(0.020)\end{array}$ & $\begin{array}{c}-0.108 \\
(0.021)\end{array}$ & $\begin{array}{c}-0.104 \\
(0.021)\end{array}$ \\
\hline 1 month before announcement & & & & $\begin{array}{c}-0.020 \\
(0.009)\end{array}$ & $\begin{array}{c}-0.015 \\
(0.010)\end{array}$ \\
\hline 2 months & & & & $\begin{array}{c}0.008 \\
(0.009)\end{array}$ & $\begin{array}{c}0.011 \\
(0.009)\end{array}$ \\
\hline 3 months & & & & $\begin{array}{c}-0.004 \\
(0.008)\end{array}$ & $\begin{array}{c}-0.001 \\
(0.009)\end{array}$ \\
\hline 4 months & & & & $\begin{array}{c}-0.002 \\
(0.008)\end{array}$ & $\begin{array}{c}0.001 \\
(0.008)\end{array}$ \\
\hline 5 months & & & & $\begin{array}{c}0.001 \\
(0.006)\end{array}$ & $\begin{array}{c}0.003 \\
(0.006)\end{array}$ \\
\hline Log labor input & $\begin{array}{c}0.641 \\
(0.090)\end{array}$ & $\begin{array}{c}0.025 \\
(0.005)\end{array}$ & $\begin{array}{c}0.023 \\
(0.005)\end{array}$ & $\begin{array}{c}0.023 \\
(0.005)\end{array}$ & $\begin{array}{c}0.012 \\
(0.014)\end{array}$ \\
\hline Lagged sales & No & Yes & Yes & Yes & Yes \\
\hline Month fixed effects & No & No & Yes & Yes & Yes \\
\hline Shop fixed effects & No & No & No & No & Yes \\
\hline Observations & 6736 & 5764 & 5764 & 5764 & 5764 \\
\hline
\end{tabular}

Notes: Estimates in columns 1 to 5 correspond to specifications in equations (1) to (5) in the text. Standard errors clustered by shop are in parentheses. 
Table 4: The impact of shop sale and closure announcements

on sales

\begin{tabular}{|c|c|c|c|}
\hline Depedent variable: log monthly sales & (1) & (2) & (3) \\
\hline SALE announcement & $\begin{array}{c}-0.063 \\
(0.013)\end{array}$ & $\begin{array}{c}-0.064 \\
(0.013)\end{array}$ & $\begin{array}{l}-0.060 \\
(0.013)\end{array}$ \\
\hline CLOSURE announcement & $\begin{array}{l}-0.244 \\
(0.065)\end{array}$ & $\begin{array}{c}-0.246 \\
(0.066)\end{array}$ & $\begin{array}{l}-0.239 \\
(0.065)\end{array}$ \\
\hline 1 month before SALE announcement & & $\begin{array}{c}-0.013 \\
(0.011)\end{array}$ & $\begin{array}{c}-0.008 \\
(0.011)\end{array}$ \\
\hline 2 months before SALE announcement & & $\begin{array}{c}0.009 \\
(0.009)\end{array}$ & $\begin{array}{c}0.011 \\
(0.010)\end{array}$ \\
\hline 3 months before SALE announcement & & $\begin{array}{c}-0.001 \\
(0.008)\end{array}$ & $\begin{array}{c}0.002 \\
(0.009)\end{array}$ \\
\hline 4 months before SALE announcement & & $\begin{array}{c}-0.004 \\
(0.009)\end{array}$ & $\begin{array}{l}-0.002 \\
(0.010)\end{array}$ \\
\hline 5 months before SALE announcement & & $\begin{array}{c}0.009 \\
(0.006)\end{array}$ & $\begin{array}{c}0.010 \\
(0.006)\end{array}$ \\
\hline 1 month before CLOSURE announcement & & $\begin{array}{c}-0.042 \\
(0.020)\end{array}$ & $\begin{array}{c}-0.032 \\
(0.021)\end{array}$ \\
\hline 2 months before CLOSURE announcement & & $\begin{array}{c}0.007 \\
(0.019)\end{array}$ & $\begin{array}{c}0.016 \\
(0.017)\end{array}$ \\
\hline 3 months before CLOSURE announcement & & $\begin{array}{c}-0.016 \\
(0.017)\end{array}$ & $\begin{array}{l}-0.006 \\
(0.019)\end{array}$ \\
\hline 4 months before CLOSURE announcement & & $\begin{array}{c}0.003 \\
(0.016)\end{array}$ & $\begin{array}{c}0.011 \\
(0.016)\end{array}$ \\
\hline 5 months before CLOSURE announcement & & $\begin{array}{c}-0.023 \\
(0.011)\end{array}$ & $\begin{array}{c}-0.014 \\
(0.013)\end{array}$ \\
\hline Log labor input & $\begin{array}{c}0.024 \\
(0.005)\end{array}$ & $\begin{array}{c}0.024 \\
(0.005)\end{array}$ & $\begin{array}{c}0.013 \\
(0.014)\end{array}$ \\
\hline Lagged sales & Yes & Yes & Yes \\
\hline Month fixed effects & Yes & Yes & Yes \\
\hline Shop fixed effects & No & No & Yes \\
\hline Observations & 5764 & 5764 & 5764 \\
\hline
\end{tabular}

Notes: Estimates in columns 1, 2 and 3 correspond to specifications in equations (3), (4) and (5), respectively. Standard errors clustered by shop are in parentheses. 
Table 5: Factors moderating the impact of sale and closure announcement on sales

\begin{tabular}{|c|c|c|c|c|c|c|c|}
\hline Dependent variable: log monthly sales & (1) & $(2)$ & (3) & (4) & $(5)$ & (6) & (7) \\
\hline \multicolumn{8}{|l|}{ Cross product of shop being SOLD with... } \\
\hline overall job satisfaction score & $\begin{array}{l}-0.024 \\
(0.021)\end{array}$ & & & & & & $\begin{array}{l}-0.034 \\
(0.035)\end{array}$ \\
\hline commitment score & & $\begin{array}{l}-0.025 \\
(0.016)\end{array}$ & & & & & $\begin{array}{l}-0.020 \\
(0.025)\end{array}$ \\
\hline reciprocity score & & & $\begin{array}{l}-0.007 \\
(0.014)\end{array}$ & & & & $\begin{array}{l}-0.019 \\
(0.013)\end{array}$ \\
\hline satisfaction with co-workers & & & & $\begin{array}{l}-0.013 \\
(0.012)\end{array}$ & & & $\begin{array}{c}0.002 \\
(0.016)\end{array}$ \\
\hline $\begin{array}{l}\text { frequency of private meetings with co- } \\
\text { workers }\end{array}$ & & & & & $\begin{array}{l}-0.004 \\
(0.015)\end{array}$ & & $\begin{array}{l}-0.012 \\
(0.013)\end{array}$ \\
\hline $\begin{array}{l}\text { share of workers with a permanent } \\
\text { contract }\end{array}$ & & & & & & $\begin{array}{l}-0.011 \\
(0.011)\end{array}$ & $\begin{array}{l}-0.019 \\
(0.012)\end{array}$ \\
\hline \multicolumn{8}{|c|}{ Cross product of shop being CLOSED with... } \\
\hline overall job satisfaction score & $\begin{array}{l}0.110 \\
(0.168)\end{array}$ & & & & & & $\begin{array}{l}-0.306 \\
(0.261)\end{array}$ \\
\hline commitment score & & $\begin{array}{c}0.192 \\
(0.097)\end{array}$ & & & & & $\begin{array}{c}0.289 \\
(0.161)\end{array}$ \\
\hline reciprocity score & & & $\begin{array}{l}0.096 \\
(0.077)\end{array}$ & & & & $\begin{array}{c}0.021 \\
(0.070)\end{array}$ \\
\hline satisfaction with co-workers & & & & $\begin{array}{l}-0.014 \\
(0.080)\end{array}$ & & & $\begin{array}{c}0.051 \\
(0.119)\end{array}$ \\
\hline $\begin{array}{l}\text { frequency of private meetings with co- } \\
\text { workers }\end{array}$ & & & & & $\begin{array}{l}-0.014 \\
(0.090)\end{array}$ & & $\begin{array}{l}-0.128 \\
(0.093)\end{array}$ \\
\hline $\begin{array}{l}\text { share of workers with a permanent } \\
\text { contract }\end{array}$ & & & & & & $\begin{array}{l}-0.114 \\
(0.054)\end{array}$ & $\begin{array}{l}-0.105 \\
(0.030)\end{array}$ \\
\hline Lagged sales & Yes & Yes & Yes & Yes & Yes & Yes & Yes \\
\hline Month fixed effects & Yes & Yes & Yes & Yes & Yes & Yes & Yes \\
\hline Shop fixed effects & Yes & Yes & Yes & Yes & Yes & Yes & Yes \\
\hline Observations & 5764 & 5764 & 5764 & 5764 & 5764 & 5764 & 5764 \\
\hline
\end{tabular}

Notes: All estimates are based on specification (5). Standard errors clustered by shop are in parentheses. 
Table 6: Regression results: Sales and customer visits

\begin{tabular}{lcc}
\hline \hline & \multicolumn{2}{c}{ Dependent variable: } \\
& Log sales & $\begin{array}{c}\text { Log customer } \\
\text { visits }\end{array}$ \\
& & \\
\hline SALE announcement & -0.048 & -0.038 \\
& $(0.015)$ & $(0.014)$ \\
1 month before & -0.004 & -0.008 \\
& $(0.012)$ & $(0.011)$ \\
2 months & 0.009 & 0.013 \\
& $(0.011)$ & $(0.010)$ \\
months & 0.003 & -0.001 \\
4 months & $(0.010)$ & $(0.008)$ \\
& 0.001 & 0.002 \\
5 months & $(0.011)$ & $(0.009)$ \\
& 0.011 & 0.009 \\
Shop fixed effects & $(0.007)$ & $(0.006)$ \\
\hline \hline
\end{tabular}

Notes: All estimates are based on specification (5). Standard errors clustered by shop are in parentheses. 